\title{
Interferon free antiviral treatment of chronic hepatitis $C$ in patients affected by $\beta$-thalassemia major
}

\author{
Elisa Biliotti ${ }^{1}$ - Donatella Palazzo ${ }^{1}$ Marco Serani $^{1} \cdot$ Alessandro M. Silvestri $^{1}$ • \\ Lorenzo Volpicelli $^{1} \cdot$ Rozenn Esvan $^{1} \cdot$ Cristiana Franchi $^{1} \cdot$ Martina Spaziante $^{1}$. \\ Francesco Sorrentino $^{2} \cdot$ Gloria Taliani $^{1}$
}

Received: 21 February 2017 / Accepted: 29 March 2017 /Published online: 5 April 2017

(C) Springer-Verlag Berlin Heidelberg 2017

\section{Dear Editor,}

Chronic hepatitis $\mathrm{C}(\mathrm{CHC})$ significantly affects the prognosis of liver disease [1] and health related quality of life (HRQOL) in patients with $\beta$-thalassemia major $[2,3]$. CHC cure is a crucial event in the prognosis of the disease, since prevents fibrosis progression, decreases the risk of hepatocellular carcinoma (HCC), and improves survival. Standard antiviral therapy with Pegylated Interferon (PEG-IFN) and Ribavirin (RBV) has long been the standard of care, despite its limited efficacy and increased ribavirin induced hematological adverse events in thalassemic patients [4]. Recently, several novel highly effective direct antiviral agents (DAAs) have been approved for HCV treatment, with impressive cure rates, higher than $90 \%$, after 8-12 weeks of therapy and mild adverse events [5], but there are no published reports documenting the efficacy, safety and impact on QOL of available interferon-free antiviral regimens in patients with $\beta$ thalassemia major.

We describe four cases of young patients with $\beta$ thalassemia major and advanced fibrosis treated with DAAs for CHC (Table 1). HCV genotype was $1 \mathrm{~b}$ in all patients except one, which had genotype 4 . Cryoglobulins were positive in two patients (cryocrit 1.6 and $3.2 \%$ ) with no organ involvement. All patients were previously non-responders to $\mathrm{PEG}-\mathrm{IFN} \pm \mathrm{RBV}$ treatment. Iron chelation drugs included subcutaneous desferrioxamine

Elisa Biliotti

elisabiliotti@yahoo.it

1 Department of Clinical Medicine, Sapienza University of Rome, viale del Policlinico 155, 00161 Rome, Italy

2 Thalassemia Unit, S. Eugenio Hospital, Rome, Italy and/or oral deferasirox. Antiviral therapy with sofosbuvir (SOF) and ledipasvir (LDV) was started for 12 weeks. All patients achieved sustained virologic response (SVR). Treatment was safe and well tolerated, kidney function remained stable, and the only adverse events were mild asthenia and headache. Iron chelation concomitant medications remained unmodified during treatment, as well as the frequency of blood transfusions. Ferritin levels decreased during therapy in three patients, but in two of them returned to baseline levels at FU3. A reduction of liver stiffness, assessed by transient elastography, occurred from baseline to FU3 in all subjects. All SF36 scales related to mental health and to physical health significantly improved at FU6 compared to baseline (Table 2).

The present case series suggests that 12 -week-combination therapy of SOF/LDV is effective and safe in transfusiondependent $\beta$-thalassemia patients with advanced liver fibrosis. Remarkably, no impact of SOF on kidney function was observed as e-GFR values remained stable during therapy and FU.

To our knowledge, no data exist on the interactions between DAAs and iron chelation drugs. We employed SOF and LDV in these patients because this drug combination is associated with limited interactions [6]. Remarkably, in none of the cases, it was necessary to modify iron chelation therapy, and no changes in transfusion requests occurred. Moreover, serum ferritin values, an indirect marker of iron chelation efficacy, showed an improvement during antiviral therapy in all patients but one who reported poor compliance to iron chelation therapy during DAA treatment.

A marked improvement of liver stiffness, which correlates with fibrosis stage assessed by liver biopsy [7], was observed in all patients. This result may be partly due to a reduction and control of liver inflammation [8]; however, an initial regression of liver fibrosis might also have occurred, which is an 
Table 1 Biochemical and virological characteristics of $\mathrm{HCV}$ patients with thalassemia major during the study period

\begin{tabular}{|c|c|c|c|c|c|}
\hline & Parameters & Baseline (T0) & $\begin{array}{l}\text { Treatment } \\
\text { week } 4 \text { (TW4) }\end{array}$ & End of treatment (EOT) & $\begin{array}{l}\text { Follow-up } \\
\text { week } 12 \text { (FU3) }\end{array}$ \\
\hline \multirow{7}{*}{$\begin{array}{l}\text { Patient } 1 \\
\text { Female } \\
42 \text { years }\end{array}$} & Hemoglobin (12-15 g/dL) & 10.4 & 12.6 & 12.7 & 12.8 \\
\hline & Total bilirubin $(0.3-1.2 \mathrm{mg} / \mathrm{dL})$ & 2.6 & 1.32 & 1.64 & 2 \\
\hline & $\operatorname{ALT}(7-35 \mathrm{U} / \mathrm{L})$ & 97 & 21 & 17 & 10 \\
\hline & $\mathrm{e}-\mathrm{GFR}\left(\mathrm{mL} / \mathrm{min} / 1.73 \mathrm{~m}^{2}\right)$ & 107 & 107 & 107 & 107 \\
\hline & Serum ferritine $(15-150 \mathrm{ng} / \mathrm{mL})$ & 184 & 130 & 88 & 166 \\
\hline & HCV-RNA (IU/mL) & 211.100 & Undetectable & Undetectable & Undetectable \\
\hline & Liver stiffness (KPa) & 10.5 & - & - & 7.1 \\
\hline \multirow{7}{*}{$\begin{array}{l}\text { Patient } 2 \\
\text { Female } \\
43 \text { years }\end{array}$} & Hemoglobin $(12-15 \mathrm{~g} / \mathrm{dL})$ & 10.9 & 11.7 & 10.8 & 11 \\
\hline & Total bilirubin $(0.3-1.2 \mathrm{mg} / \mathrm{dL})$ & 1.5 & 1.2 & 1.6 & 1.67 \\
\hline & ALT (7-35 U/L) & 24 & 14 & 11 & 13 \\
\hline & e-GFR $\left(\mathrm{mL} / \mathrm{min} / 1.73 \mathrm{~m}^{2}\right)$ & 112 & 112 & 106 & 112 \\
\hline & Serum ferritine $(15-150 \mathrm{ng} / \mathrm{mL})$ & 834 & 556 & 626 & 380 \\
\hline & HCV-RNA (IU/mL) & 1.121 .181 & Undetectable & Undetectable & Undetectable \\
\hline & Liver stiffness (KPa) & 10 & - & - & 7.3 \\
\hline \multirow{7}{*}{$\begin{array}{l}\text { Patient } 3 \\
\text { Male } \\
37 \text { years }\end{array}$} & Hemoglobin (12-15 g/dL) & 9.7 & 9.9 & 9.4 & 9.6 \\
\hline & Total bilirubin $(0.3-1.2 \mathrm{mg} / \mathrm{dL})$ & 2.72 & 2.81 & 2.63 & 2.38 \\
\hline & ALT (7-35 U/L) & 62 & 26 & 24 & 13 \\
\hline & $\mathrm{e}-\mathrm{GFR}\left(\mathrm{mL} / \mathrm{min} / 1.73 \mathrm{~m}^{2}\right)$ & 145 & 128 & 138 & 138 \\
\hline & Serum ferritine $(15-150 \mathrm{ng} / \mathrm{mL})$ & 544 & 667 & 346 & 462 \\
\hline & HCV-RNA (IU/mL) & 473.982 & Undetectable & Undetectable & Undetectable \\
\hline & Liver stiffness (KPa) & 10.4 & - & - & 8.1 \\
\hline \multirow{7}{*}{$\begin{array}{l}\text { Patient } 4 \\
\text { Male } \\
38 \text { years }\end{array}$} & Hemoglobin (12-15 g/dL) & 11.5 & 10.9 & 11.1 & 10.7 \\
\hline & Total bilirubin $(0.3-1.2 \mathrm{mg} / \mathrm{dL})$ & 2.03 & 1.11 & 1.31 & 1.41 \\
\hline & ALT (7-35 U/L) & 47 & 19 & 35 & 42 \\
\hline & e-GFR $\left(\mathrm{mL} / \mathrm{min} / 1.73 \mathrm{~m}^{2}\right)$ & 128 & 128 & 128 & 128 \\
\hline & Serum ferritine $(15-150 \mathrm{ng} / \mathrm{mL})$ & 420 & 684 & 621 & 650 \\
\hline & HCV-RNA (IU/mL) & 4.419 .000 & Undetectable & Undetectable & Undetectable \\
\hline & Liver stiffness (KPa) & 10 & - & - & 7 \\
\hline
\end{tabular}

important outcome in thalassemic patients, given their rapid fibrosis progression.
Both thalassemia major and $\mathrm{CHC}$ affect HRQOL [2, 3, 9], but the contribution of $\mathrm{CHC}$ to the impaired HRQOL of

Table 2 Physical and mental health related quality of life (HRQOL) scores in SF-36 scales before and 24 weeks after antiviral treatment of HCV patients with Thalassemia major

\begin{tabular}{|c|c|c|c|c|c|c|c|c|c|}
\hline $\begin{array}{l}\text { Patient } \\
\text { number }\end{array}$ & Time & $\begin{array}{l}\text { Physical } \\
\text { functioning }\end{array}$ & Role-physical & $\begin{array}{l}\text { Bodily } \\
\text { pain }\end{array}$ & $\begin{array}{l}\text { General } \\
\text { health }\end{array}$ & Vitality & $\begin{array}{l}\text { Social } \\
\text { functioning }\end{array}$ & Role-emotional & $\begin{array}{l}\text { Mental } \\
\text { health }\end{array}$ \\
\hline \multirow[t]{2}{*}{1} & T0 & 75 & 75 & 64 & 30 & 60 & 50 & 66 & 56 \\
\hline & FU6 & 85 & 100 & 100 & 25 & 85 & 87 & 100 & 68 \\
\hline \multirow[t]{2}{*}{2} & $\mathrm{~T} 0$ & 50 & 50 & 41 & 5 & 30 & 37 & 33 & 40 \\
\hline & FU6 & 85 & 100 & 84 & 56 & 85 & 87 & 100 & 76 \\
\hline \multirow[t]{2}{*}{3} & $\mathrm{~T} 0$ & 90 & 100 & 84 & 10 & 50 & 75 & 100 & 52 \\
\hline & FU6 & 95 & 100 & 100 & 37 & 85 & 100 & 100 & 76 \\
\hline \multirow[t]{2}{*}{4} & $\mathrm{~T} 0$ & 75 & 80 & 72 & 20 & 50 & 55 & 60 & 54 \\
\hline & FU6 & 91 & 94 & 90 & 35 & 83 & 90 & 100 & 70 \\
\hline
\end{tabular}


thalassemic patients has never been assessed. In our case series, a striking improvement of physical and mental dimensions of health, assessed by SF-36 questionnaire, occurred in all patients after $\mathrm{HCV}$ cure. This finding suggests that $\mathrm{HCV}$ infection plays a prominent, though probably underestimated, role on the impairment of HRQOL of thalassemic patients, and that antiviral treatment has the capacity to affect also this important aspect of patient's health.

\section{Compliance with ethical standards}

Conflict of interest Gloria Taliani has received advisory board and speaking fees from AbbVie, BMS, MSD, Roche, Janssen and Gilead. The other authors have nothing to disclose regarding funding or conflict of interest with respect to this manuscript.

\section{References}

1. Di Marco V, Capra M, Gagliardotto F, Borsellino Z, Cabibi D, Barbaria $F$ et al (2008) Liver disease in chelated transfusiondependent thalassemics: the role of iron overload and chronic hepatitis C. Haematologica 93(8):1243-1246

2. Gollo G, Savioli G, Balocco M, Venturino C, Boeri E, Costantini M, Forni GL (2013) Changes in the quality of life of people with thalassemia major between 2001 and 2009. Patient Prefer Adherence 7:231-236

3. Dhirar N, Khandekar J, Bachani D, Mahto D (2016) Thalassemia major: how do we improve quality of life? Spring 5(1):1895

4. Di Marco V, Capra M, Angelucci E, Borgna-Pignatti C, Telfer P, Harmatz $P$ et al (2010) Management of chronic viral hepatitis in patients with thalassemia: recommendations from an international panel. Blood 116(16):2875-2883

5. Asselah T, Boyer N, Saadoun D, Martinot-Peignoux M, Marcellin P (2016) Direct-acting antivirals for the treatment of hepatitis C virus infection: optimizing current IFN-free treatment and future perspectives. Liver Int 36:47-57

6. Talavera Pons S, Boyer A, Lamblin G, Chennell P, Châtenet F-T, Nicolas $C$ et al (2017) Managing drug-drug interactions with new direct-acting antiviral agents in chronic hepatitis $\mathrm{C}$. Br J Clin Pharmacol 83(2):269-293

7. Fraquelli M, Cassinerio E, Roghi A, Rigamonti C, Casazza G, Colombo $\mathrm{M}$ et al (2010) Transient elastography in the assessment of liver fibrosis in adult thalassemia patients. Am J Hematol 85(8): 564-568

8. Bachofner JA, Valli PV, Kröger A, Bergamin I, Künzler P, Baserga A et al (2017) Direct antiviral agent treatment of chronic hepatitis C results in rapid regression of transient elastography and fibrosis markers fibrosis-4 score and aspartate aminotransferase-platelet ratio index. Liver Int 37(3):369-376

9. Spiegel BM, Younossi ZM, Hays RD, Revicki D, Robbins S, Kanwal F (2005) Impact of hepatitis $C$ on health related quality of life: a systematic review and quantitative assessment. Hepatology 41(4):790-800 